\title{
A proliferation-dependent bystander effect in primary porcine and human urothelial explants in response to targeted irradiation
}

\author{
OV Belyakov ',2, M Folkard', C Mothersill', KM Prise ${ }^{*, 1}$ and BD Michael' \\ 'Gray Cancer Institute, PO Box 100, Mount Vernon Hospital, Northwood, Middlesex HA6 2JR, UK; ${ }^{2}$ Radiation and Environmental Science Centre, \\ Dublin Institute of Technology, Kevin Street, Dublin 8, Ireland
}

\begin{abstract}
The aim of this study was to test whether radiation-induced bystander effects are involved in the response of multicellular systems to targeted irradiation. A primary explant technique was used that reconstructed the in vivo microarchitecture of normal urothelium with proliferating and differentiated cells present. Sections of human and porcine ureter were cultured as explants and irradiated on day 7 when the urothelial outgrowth formed a halo around the tissue fragment. The Gray Cancer Institute charge particle microbeam facility allowed the irradiation of individual cells within the explant outgrowth with a predetermined exact number of ${ }^{3} \mathrm{He}^{2+}$ ions (which have very similar biological effectiveness to $\alpha$-particles). A total of 10 individual cell nuclei were irradiated with $10{ }^{3} \mathrm{He}^{2+}$ ions either on the periphery, where proliferating cells are located, or at the centre of the explant outgrowth, which consisted of terminally differentiated cells. Samples were fixed 3 days after irradiation, stained and scored. The fraction of apoptotic and micronucleated cells was measured and a significant bystander-induced damage was observed. Approximately 2000-6000 cells could be damaged by the irradiation of a few cells initially, suggesting a cascade mechanism of cell damage induction. However, the fraction of micronucleated and apoptotic cells did not exceed I-2\% of the total number of the cells within the explant outgrowth. It is concluded that the bystander-induced damage depends on the proliferation status of the cells and can be observed in an in vitro explant model. British Journal of Cancer (2003) 88, 767-774. doi:I0.1038/sj.bjc.6600804 www.bjcancer.com (C) 2003 Cancer Research UK
\end{abstract}

Keywords: bystander effect; microbeam; urothelium; explant; proliferation

Until recently, it has been commonly accepted that the biological consequences following radiation exposure are attributable to direct DNA damage. According to this paradigm, DNA damage occurs during or very shortly after irradiation of the nuclei in targeted cells, and the potential for biological consequences can be expressed within one or two cell generations (Little, 2000). Several lines of evidence have now emerged that challenge the idea that the biological effects result from targeted damage to DNA. These new effects have been termed 'nontargeted' and include radiationinduced bystander effects, genomic instability, low-dose hypersensitivity and adaptive responses (Ward, 1999). A common feature of 'nontargeted' effects is that they are significant responses at low doses of relevance to fractionated radiotherapy and protection level exposures.

The radiation-induced bystander effect is a phenomenon whereby cellular damage (sister chromatid exchanges (Nagasawa and Little, 1992; Lehnert and Goodwin, 1997), chromosome aberrations (Little et al, 1997; Lorimore et al, 1998), apoptosis (Mothersill and Seymour, 1997; Mothersill et al, 2000), micronucleation (Prise et al, 1998; Belyakov et al, 2001), transformation (Sigg et al, 1997), mutations (Zhou et al, 2000) and changes of gene expression (Hickman et al, 1994; Azzam et al, 1998)) are expressed in unirradiated neighbouring cells close to an irradiated cell or

*Correspondence: Dr KM Prise; E-mail: prise@gci.ac.uk

Received 8 August 2002; revised II November 2002; accepted 25 November 2002 cells. The mechanisms underpinning the bystander effect are not yet known. However, there is evidence that the bystander effect may have at least two separate pathways for the transfer of damage from irradiated cells to unirradiated neighbours: through gap junctions or by cell-culture-mediated factors.

Several studies (Azzam et al, 1998, 2001) have demonstrated that the bystander effect is dependent on gap junction intercellular communication (GJIC) in confluent cultures of primary human diploid fibroblasts exposed to low fluences of $\alpha$-particles. These showed that p53 and p21 mediated pathways are activated (Azzam et al, 2000). Other studies reported that a p53-mediated signalling pathway could be activated in the bystander effect (Hickman et al, 1994), after low-dose $\alpha$-particle irradiation of rat lung epithelial cells. Flow cytometric analysis of the fraction of cells with elevated levels of $\mathrm{p} 53$ protein detected an increased expression in a higher proportion of cells than were hit by an $\alpha$-particle.

The other proposed mechanism of the bystander effect is mediation by secretion of factors into the culture medium (Mothersill and Seymour, 1997). A series of studies (Narayanan et al, 1997) suggests a mechanism in which the irradiated cells secrete cytokines or other factors that act to increase intracellular levels of reactive oxygen species in unirradiated cells (Iyer and Lehnert, 2000b). In particular, it was demonstrated that the culture medium harvested from the cells irradiated with low fluences of $\alpha$ particles could induce an increase in sister chromatid exchanges when incubated with unirradiated test cells. For reactive oxygen species, a role for superoxide and hydrogen peroxide has been reported, although these may only be downstream consequences of 
bystander initiation. The elimination of the bystander effect by heat treatment of the harvested medium or by treatment of irradiated cells with protein synthesis inhibitors suggests that the secreted factors could be proteins (Lehnert and Goodwin, 1997).

Little is known regarding the role of bystander effects in multicellular systems. The radiosensitivity of HPV-G and HaCaT epithelial cell lines irradiated within microcolonies ( $>50$ cells) was found to be lower than when they were irradiated as single cells (Cummins et al, 1999). A recent study (Bishayee et al, 1999) detected a pronounced bystander effect in a V79 three-dimensional (3D) tissue culture model labelled with ${ }^{3} \mathrm{H}$ when the isotope was localised in the cell nucleus and distributed nonuniformly among the cells. Other studies (Jen et al, 1991) have found that the radiosensitivity of mouse kidney cells that were irradiated under in vivo conditions in situ or in vitro as fragments was higher than those irradiated in vitro as single cells. More recently, irradiated haemopoietic stem cells were observed to produce a bystander response in vivo when these were transplanted back into animals (Watson et al, 2000).

Our own studies (Prise et al, 1998; Belyakov et al, 2001) demonstrated that irradiation of a single human fibroblast with a single ${ }^{3} \mathrm{He}^{2+}$ particle produced a significant bystander effect with a 2-3-fold increase in the micronucleated and apoptotic cells fraction in the surrounding unirradiated population. Further increases of dose to the irradiated cell did not increase the number of cells responding. The aim of this study was to test whether bystander responses are induced in a primary tissue model where individual cells had been targeted with radiation. For this, we utilised a ureter explant system developed from either human or porcine samples.

\section{MATERIALS AND METHODS}

\section{Ureter samples}

Human ureter samples were obtained for Dr C Mothersill, from consenting patients undergoing reconstructive surgery for benign conditions at local hospitals. The studies had ethical approval from the hospitals' ethics committees and from the Dublin Institute of Technology (DIT). Samples were placed in sterile physiological saline immediately on removal from the patient and shipped on ice to the laboratory. Explants were normally established within $24 \mathrm{~h}$.

Dr Mohi Rezvani and Neil Hubbard (Churchill Hospital, University of Oxford) generously provided porcine ureter samples. They were obtained from 10 to 72 -week-old farm pigs during post-mortem examination. These animals were maintained in compliance with the Animal (Scientific Procedures) Act 1986 (Workman et al, 1998). Samples were placed in sterile 'transport medium' after removal and shipped on ice. Transport medium (Southgate et al, 1995) was based on RPMI 1640 with L-glutamine (Sigma, Poole, UK) containing $20 \mathrm{~mm}$ HEPES, $10 \%\left(\mathrm{vv}^{-1}\right)$ foetal calf serum (Sigma, Poole, UK) and $20 \mathrm{IU} \mathrm{ml}^{-1}$ of aprotinin (Sigma, Poole, UK) with additions of penicillin $\left(100 \mathrm{IU} \mathrm{ml}^{-1}\right)$ and streptomycin $\left(100 \mu \mathrm{g} \mathrm{ml}^{-1}\right),\left(50 \mu \mathrm{g} \mathrm{ml}^{-1}\right)$ fungisone (Gibco, Paisley, UK) and nystatin (Sigma, Poole, UK). Explants were normally established within $24 \mathrm{~h}$.

\section{Primary explant technique}

An explant approach (Mothersill, 1998) was used for studying bystander effects under in vivo-like conditions where proliferating and differentiated cells were present. Ureter samples were trimmed from fat and connective tissue, opened with fine scissors longitudinally and cut into segments of approximately $2-3 \mathrm{~mm}^{2}$ for explantation. Samples were treated with a $0.25 \%\left(\mathrm{w} \mathrm{v}^{-1}\right)$ trypsin solution (Gibco, Paisley, UK) containing $10 \mathrm{mg} \mathrm{ml}^{-1}$ collagenase IV (Sigma, Poole, UK) in Hank's balanced solution (Sigma, Poole,
UK) and incubated for $30 \mathrm{~min}$ at $37^{\circ} \mathrm{C}$. Ureter fragments were then plated into specially designed dishes (Folkard et al, 1997b) consisting of a $34 \mathrm{~mm}$ diameter base composed of a $1.5 \mu \mathrm{m}$ thick mylar membrane (Goodfellow, Cambridge, UK) for microbeam experiments or in T25 tissue culture flasks (Primaria, Falcon, Marathon Lab Supplies, London, UK) for cell growth measurements and BUdR cell proliferation measurements. The dishes contained $2 \mathrm{ml}$ of serum rich 'start-up' medium for initial outgrowth formation. This was based on RPMI 1640 with Lglutamine (Sigma, Poole, UK), containing $13 \%\left(\mathrm{vv}^{-1}\right)$ foetal calf serum and $7 \%\left(\mathrm{vv}^{-1}\right)$ horse serum (Sigma, Poole, UK) with additions of $100 \mathrm{mIU}$ insulin (Sigma, Poole, UK), $1 \mathrm{mg} \mathrm{ml}^{-1}$ hydrocortisone (Sigma, Poole, UK), $30 \mathrm{ng} \mathrm{ml}^{-1}$ human recombinant EGF (Sigma, Poole, UK), penicillin $\left(100 \mathrm{IU} \mathrm{ml}^{-1}\right)$ and streptomycin $\left(100 \mu \mathrm{g} \mathrm{ml}^{-1}\right),\left(50 \mu \mathrm{g} \mathrm{ml}^{-1}\right)$ fungisone (Gibco, Paisley, UK) and nystatin (Sigma, Poole, UK).

After $2-3$ days of incubation $\left(37^{\circ} \mathrm{C}\right.$ in an atmosphere of $95 \%$ air and $5 \% \quad \mathrm{CO}_{2}$ ) the medium was replaced with serum-free Keratinocyte Growth Medium (Clonetics, UK) or KeratinocyteSFM (Gibco, Paisley, UK) and incubated for a further 4-5 days. A typical 7-day-old, human ureter urothelium outgrowth was a few millimetres in diameter (Figure 1A) and consisted mainly of a monolayer although with a few dense regions. The 'two media' technique was developed to avoid contamination of the outgrowth with fibroblasts and to promote differentiation of the urothelial cells (Mothersill, 1998). Staining with pan anticytokeratin antibodies (Sigma, Poole, UK) was used in selected cases to check the
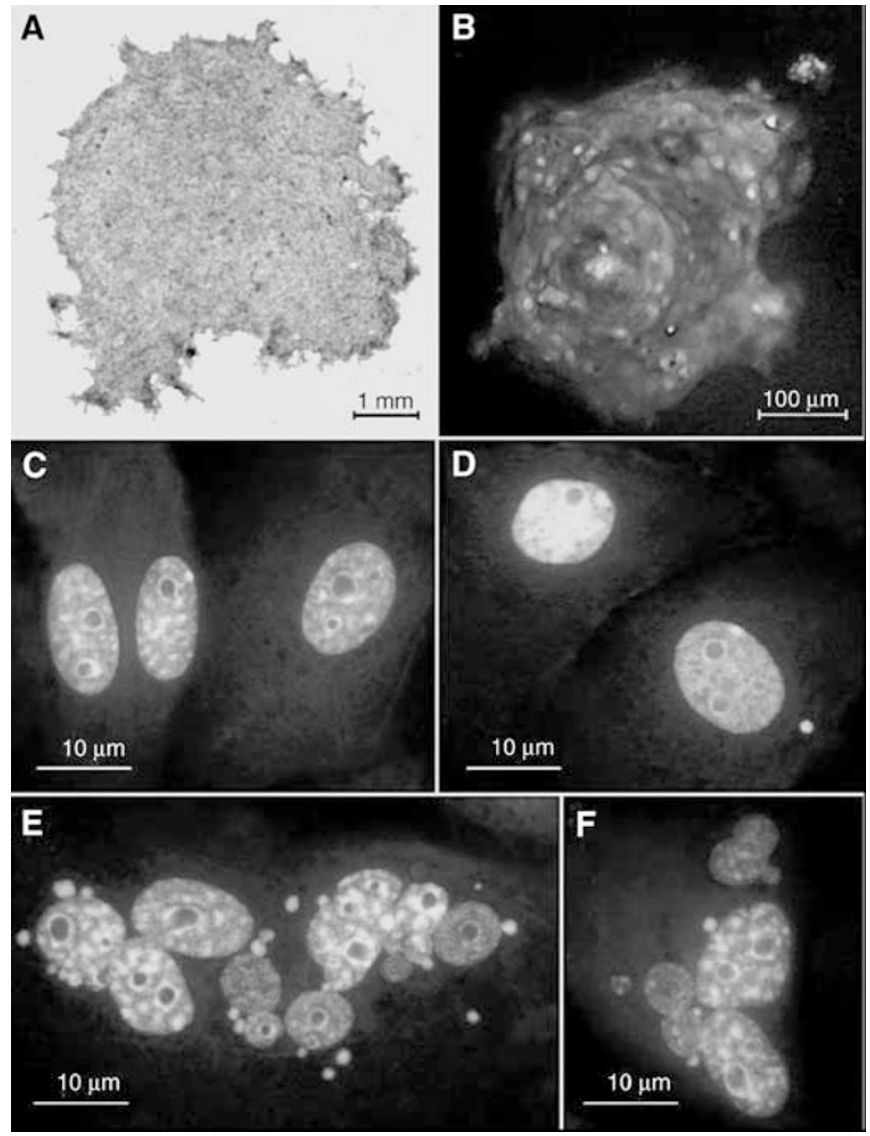

Figure I (A) Phase contrast image of a 7-day-old human urothelium explant outgrowth. (B) Human ureter outgrowth stained with pan anticytokeratin antibodies, FITC/PI staining at day 3. Images of normal porcine urothelial cells within the explant outgrowth $(\mathbf{C})$, micronucleated cells (D), and apoptotic cell (E, F), all stained with acridine orange. 
explant outgrowth for fibroblast contamination following the method of Hutton et al (1993). Cytokeratin immunostaining is a marker for epithelial cell lines. Pan cytokeratin FITC conjugated antibodies (Monoclonal clone no. C 11, mouse, IgG1, Sigma, Poole, $\mathrm{UK}$ ) were used to visualise the marker (Figure 1B). At the time of irradiation on day 7 , fibroblasts were completely eliminated from the outgrowth.

\section{Microbeam irradiation}

The Gray Cancer Institute charged particle microbeam (Folkard et al, 1997a,b) allowed the irradiation of single cells with a precise number of particles. All irradiations were performed with ${ }^{3} \mathrm{He}^{2+}$

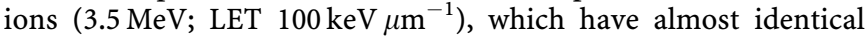
track structure to that of $\alpha$-particles. The explant outgrowth was irradiated through the base of the microbeam dish.

Cell nuclei were visualised by staining with $1 \mu \mathrm{M}$ Hoechst 33258 (Sigma, Poole, UK) in KGM medium for $1 \mathrm{~h}$ before irradiation. During the irradiation, the ureter explant outgrowth was incubated with $20 \mu \mathrm{M}$ HEPES KGM-based medium at room temperature. A total of 10 individual cell nuclei were irradiated each with $10{ }^{3} \mathrm{He}^{2+}$ particles in a 7-day-old explant outgrowth. Cell nuclei to be irradiated were randomly selected at the periphery (Figure 4A, inset) or at the centre of the outgrowth (Figure $4 \mathrm{~B}$, inset) and then positioned over the collimator using the microbeam stage. The particles were delivered to a single location at the centre of each nucleus with high precision ( $>99 \%$ within $2 \mu \mathrm{m}$ ) and the number of delivered particles was counted with a particle detector (Folkard et al, 1997a,b). The irradiation procedure typically took about 15 min after which samples were incubated in fresh KGM medium at $37^{\circ} \mathrm{C}$ in $95 \%$ air and $5 \% \mathrm{CO}_{2}$ for up to 3 days prior to scoring. Control dishes were treated in exactly the same way but not irradiated. Typically, an experimental set consisted of four irradiated and two control explants originating from the same sample.

\section{Scoring of micronucleated and apoptotic cells}

On day 3 after irradiation the samples were washed in phosphatebuffered saline (PBS), fixed in $100 \%$ methanol and stained for 20 min with $0.5 \%\left(\mathrm{wv}^{-1}\right)$ acridine orange (Sigma, Poole, UK), destained in PBS for $1 \mathrm{~h}$, air-dried and scored using a fluorescent microscope. Typical normal urothelial cells are shown in (Figure 1C). Samples were scored for the presence of micronucleated (Figure 1D) and apoptotic (Figure 1E, F) cells measured as total cell damage (Abend et al, 1995, 2000). Micronuclei appeared as green-coloured round bodies separated from the main nucleus as previously described (Belyakov et al, 1999). Apoptotic cells were classified on the basis of morphological criteria (Kerr et al, 1972). The number of cells with micronuclei and apoptotic cells were determined for each dish. During the scoring only the micronucleated and apoptotic cells were registered using a ZeissAxioskope fluorescent microscope and a cooled CCD camera system (Photonic Science, UK). The total number of cells within an explant outgrowth was estimated by measuring the explant size using a specially constructed imaging system (Vojnovic, 1996). The total number of cells within the explant outgrowth was calculated using random measurements of cell density per $100 \mu \mathrm{m}^{2}$ for each individual explant outgrowth. Taken together, this allowed estimates of the growth kinetics of the explant outgrowth to be made. The spatial distribution of cell damage was assessed on selected samples. It was obtained by scanning a straight line across an explant in $0.1 \mathrm{~mm}$ steps and counting the number of damaged and the total number of cells in each field of view (typically $80-120$ cells per field of view). Fractions of micronucleated and apoptotic cells were calculated per field of view from one side of the explant to the other.
Cell proliferation was measured by adding $10 \mu \mathrm{M}$ BUdR (Sigma, Poole, UK) in culture medium for 3 days, to assess the total number of cells undergoing division after irradiation and before fixing 3 days later. Samples were stained with anti-BUdR (mouse IgG1) antibodies (Sigma, Poole, UK) and visualised with FITC mouse IgG (whole molecule) conjugated antibodies (Sigma, Poole, UK). A few explants were examined using antibodies to Uroplakin III, a specific marker of terminal urothelial differentiation on day 7. Explants were fixed and stained with Uroplakin III antibodies (Reseach Diagnostics, Inc., USA) and visualised with FITC conjugated antibodies (Sigma, Poole, UK). Scoring of the cells was performed by scanning a straight line across the explant in $0.1 \mathrm{~mm}$ steps under low magnification. The fractions of BUdR or Uroplakin III-positive cells were calculated per field of view.

\section{Statistical analysis}

Cell damage data represent the mean and standard deviation for between two and four individual explants for each sample. In the case of cell kinetics, 10 individual explants were measured from each sample, with the mean and the standard error calculated. Individual explants were all number-coded and were scored blind. Significance tests were made using the Student's $t$-test.

\section{RESULTS}

In this study, we have used both human and porcine urothelial explant outgrowths and compared growth dynamics, patterns of proliferation and differentiation. Cell growth assays were performed in parallel to microbeam irradiation experiments. Microbeam irradiations were performed on day 7 when the explant outgrowth was in an exponential growth phase and consisted predominantly of quiescent cells (results not shown). The explant outgrowth doubled in size within 2-3 days. The doubling time for primary urothelial cell under stimulated in vitro cultivation conditions is about $56 \pm 5.6 \mathrm{~h}$ (Petzoldt et al, 1994). However, in the explant outgrowth, only a small fraction (about 10\%) of the cells was actively proliferating.

A BUdR cell proliferation assay demonstrated that the proliferating cells were concentrated on the periphery of the explant outgrowth (Figure 2B). This pattern essentially reconstructs in two dimensions the normal 3D microarchitecture of urothelium in vivo (Reznikoff et al, 1983). Urothelial differentiation was measured in nonirradiated samples by immunostaining with antibodies against Uroplakin III. This is a specific marker for terminal urothelial differentiation and staining was much more specific than in the case of earlier pilot experiments that used an array of WGA, DBA and PNA lectins (Sigma, Poole, UK, according to the methods developed by Fujiyama et al (1995) data not shown). A typical example of the nonirradiated pattern of differentiation within the urothelial explant outgrowth is represented in Figure 2C. It can be clearly seen that differentiated cells tend to concentrate at the centre of the outgrowth. Normally, $50-70 \%$ of cells within a mature urothelial explant outgrowth would be differentiated under the conditions used here. No significant differences in the growth kinetics and patterns of proliferation and differentiation were observed between the human or porcine samples.

The results of experiments with localised irradiation of 10 cells spaced at the periphery of human urothelium explant outgrowth, each with $10{ }^{3} \mathrm{He}^{2+}$ particles is shown in Figure 3. The fraction of damaged (apoptotic and micronucleated) cells was considerably higher in irradiated explants in comparison with controls. Typically, $10 \%$ of the damaged cells were apoptotic, according to the morphological criteria. The fraction of damaged cells was obtained by dividing of the number of apoptotic and micronucleated cells within the entire explant by the total number of 

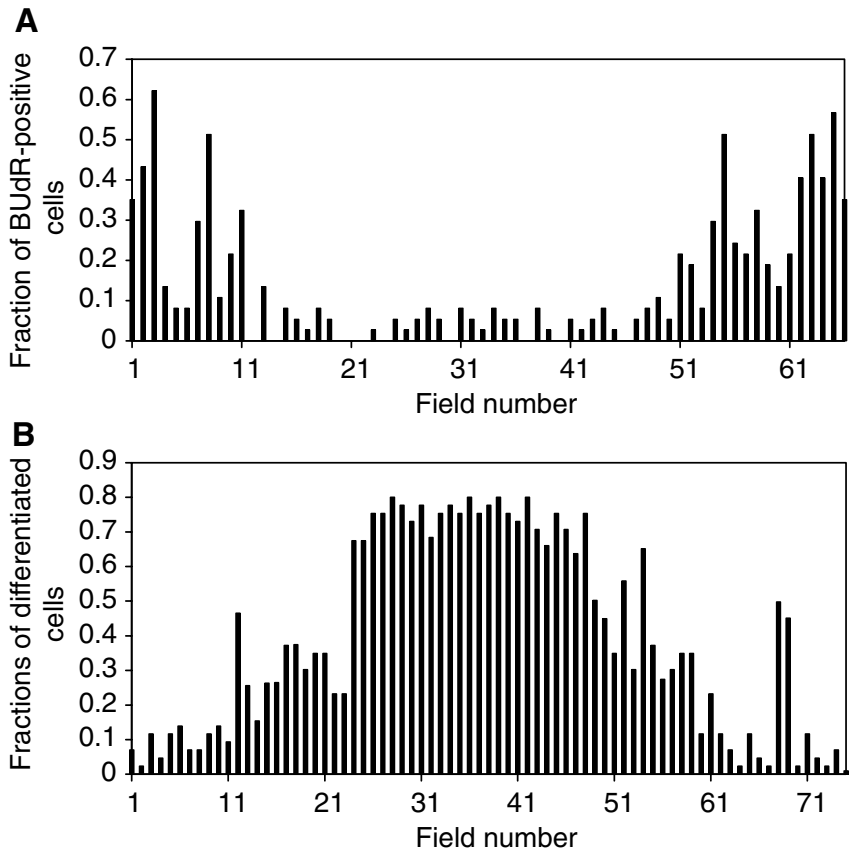

Figure 2 (A) BUdR cell proliferation assay with porcine urothelium explant outgrowth. The graph represents the spatial distribution of BudRpositive cells within a cross-section of a 10-day-old porcine urothelium explant outgrowth. Cells were scored across the explant in $0.1 \mathrm{~mm}$ steps. (B) Fraction of differentiated cells measured with Uroplakin III immunostaining in porcine urothelial explant outgrowths within a cross-section of a control, I0-day-old porcine urothelium explant outgrowth.

cells scored. There was no significant difference, in the fraction of micronucleated and apoptotic cells present, between explants, which had not been exposed to radiation, and dishes containing explants where only the medium was irradiated (data not shown). A significant variation in the background levels of micronucleated and apoptotic cells for different samples was observed, which is typical for primary samples because of genetic and age-dependent variations between individuals. Even although only 10 cells were irradiated at the actively proliferating edge of the human explant outgrowth, up to a several thousand additionally micronucleated and apoptotic cells $(1700-5700)$ were observed 3 days after irradiation (Table 1). The mean number of additional damaged cells was calculated by subtraction of the mean background fraction of micronucleated and apoptotic cells from the mean

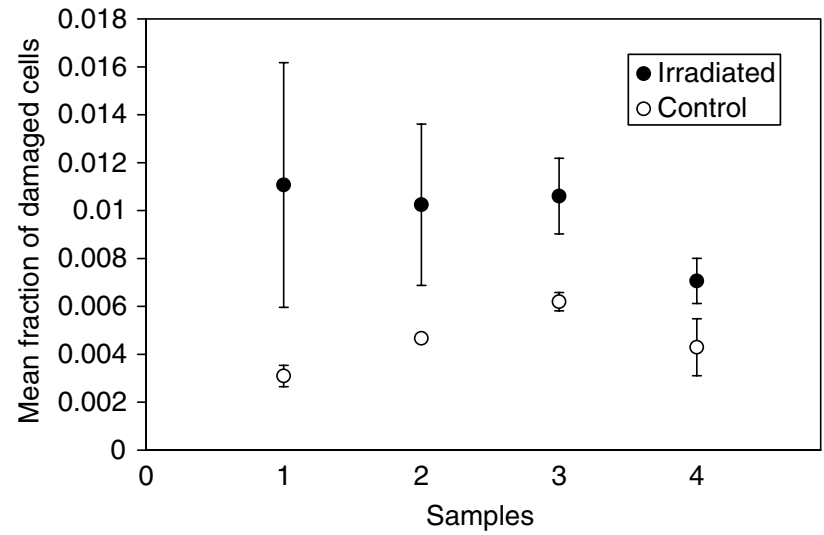

Figure 3 Fraction of damaged cells after microbeam irradiation at the periphery of a human urothelial explant outgrowth. A total of 10 cells were irradiated at the edge of each explant $\left(10^{3} \mathrm{He}^{2+}\right.$ particles per cell). Samples were fixed, stained and scored on day 3 after irradiation. Error bars represent standard deviation of the means. Each sample was from a separate donor ureter.

fraction for irradiated explants within one sample (derived from the same individual) and multiplied by the mean calculated number of cells within the explant outgrowth for this sample.

In the rest of this study, porcine explants were used, with individual urothelial cells irradiated within the 7-day-old explants located either on the periphery, where proliferating cells are located or at the centre of the explant outgrowth, which consisted of terminally differentiated cells. The results of experiments where 10 cells were irradiated at the periphery of porcine urothelium explant outgrowth with $10{ }^{3} \mathrm{He}^{2+}$ particles are shown in Figure 4A. Five samples from five different pigs were examined. The fractions of damaged cells (apoptotic and micronucleated) were scored on day 3 after irradiation. Irradiated explants demonstrated considerably higher numbers of damaged cells in comparison with the controls (Table 2). Interestingly, the overall response to microbeam irradiation of porcine ureter explant outgrowth was not considerably different from those obtained with the human samples (both irradiated at the periphery). Again, a significant interindividual variation in the response was observed.

In contrast, we did not get a statistically different level of micronucleated and apoptotic cells after irradiation of 10 cells at the centre of the porcine urothelial explant outgrowth, where mainly terminally differentiated cells are present (Figure 4B). Five samples from five individual pigs (different from those of the

Table I Results of experiments of irradiation with $10^{3} \mathrm{He}^{2+}$ particles of 10 individual cell nuclei each distributed on the periphery of a 7 -day-old human ureter explant outgrowth

\begin{tabular}{|c|c|c|c|c|c|c|c|}
\hline \multirow[b]{2}{*}{ Sample } & \multicolumn{3}{|c|}{ Control } & \multicolumn{3}{|c|}{ Irradiated } & \multirow[b]{2}{*}{$\begin{array}{c}\text { Mean calculated } \\
\text { number of } \\
\text { additionally } \\
\text { damaged cells }^{\mathbf{a}}\end{array}$} \\
\hline & $\begin{array}{l}\text { Mean number of } \\
\text { damaged cells }\end{array}$ & $\begin{array}{c}\text { Mean calculated } \\
\text { number of cells } \\
\text { within explant } \\
\text { outgrowth }\left(m_{c}\right)\end{array}$ & $\begin{array}{c}\text { Mean fraction of } \\
\text { damaged cells } \pm \text { s.d. } \\
(f c)\end{array}$ & $\begin{array}{l}\text { Mean number of } \\
\text { damaged cells }\end{array}$ & $\begin{array}{l}\text { Mean calculated } \\
\text { number of cells } \\
\text { within explant } \\
\text { outgrowth }\left(m_{\mathrm{l}}\right)\end{array}$ & $\begin{array}{c}\text { Mean fraction of } \\
\text { damaged cells } \pm \text { s.d. } \\
\left(f_{\mathrm{I}}\right)\end{array}$ & \\
\hline । & 2433 & $7.8 \times 10^{5}$ & $0.0031 \pm 0.0004$ & 7074 & $6.4 \times 10^{5}$ & $0.0111 \pm 0.0051$ & 5689 \\
\hline 2 & 3279 & $7.0 \times 10^{5}$ & $0.0047^{b}$ & 6267 & $6.1 \times 10^{5}$ & $0.0102 \pm 0.0032$ & 3608 \\
\hline 3 & 3075 & $5.0 \times 10^{5}$ & $0.0062 \pm 0.0004$ & 5217 & $4.9 \times 10^{5}$ & $0.0106 \pm 0.0022$ & 2174 \\
\hline 4 & 2604 & $6.1 \times 10^{5}$ & $0.0043 \pm 0.0012$ & 4215 & $5.9 \times 10^{5}$ & $0.0071 \pm 0.0015$ & 1679 \\
\hline
\end{tabular}

Mean number of additionally damaged cells is equal to $\left(f_{1}-f_{C}\right) \times\left(m_{C}+m_{1}\right) / 2$

bSingle explant only. 

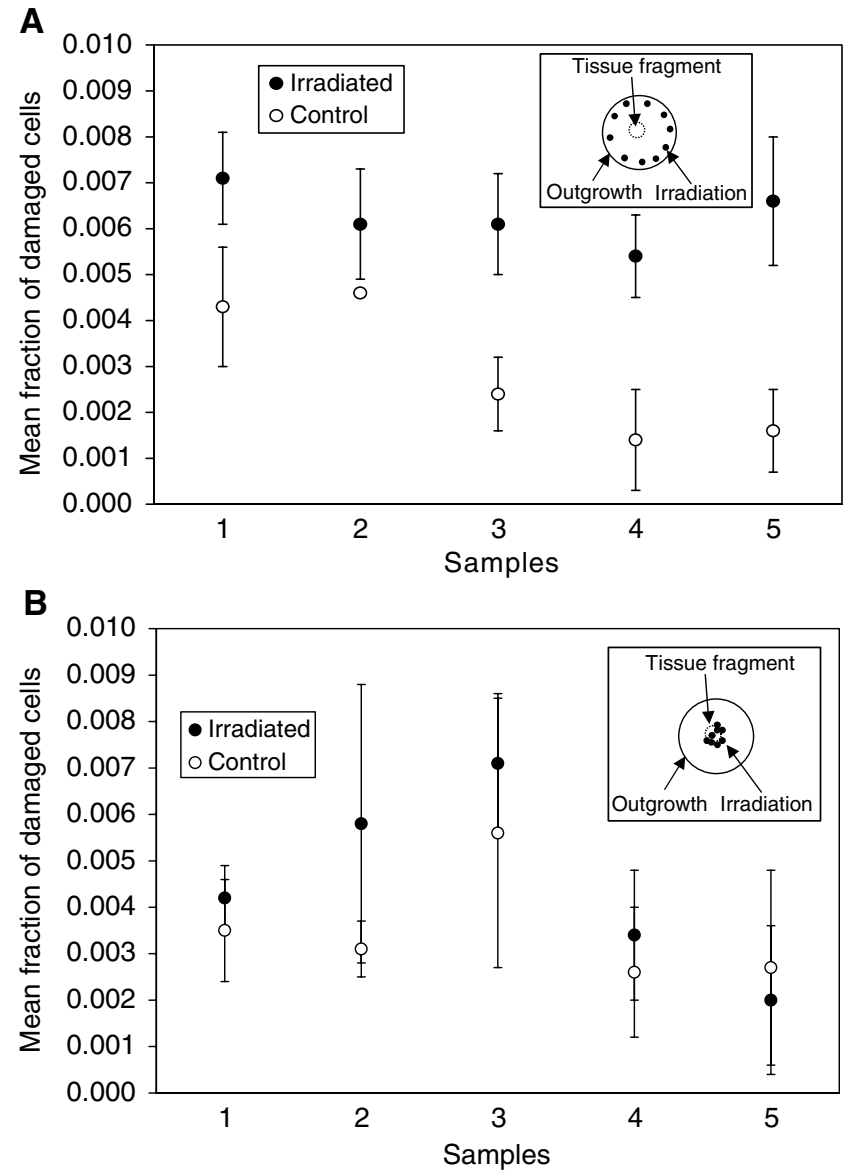

Figure 4 (A) Fraction of damaged cells after microbeam irradiation at the periphery of porcine urothelial explant outgrowth, 10 cells were irradiated at the edge of each explant $\left(10{ }^{3} \mathrm{He}^{2+}\right.$ particles per cell). (B) Fraction of damaged cells after microbeam irradiation at the centre of porcine urothelial explant outgrowth, 10 cells have been irradiated at the centre of each explant $\left(10{ }^{3} \mathrm{He}^{2+}\right.$ particles per cell). Samples were fixed, stained and scored on day 3 after irradiation. Error bars represent standard deviation of the means.

previous set) were examined. Larger standard deviations in comparison with the set of data with irradiation of the explant periphery suggest a less uniform response, which may be due to the presence of some proliferating cells within the centre of the outgrowth (Figure 2B). Overall, our finding demonstrates that 10
A

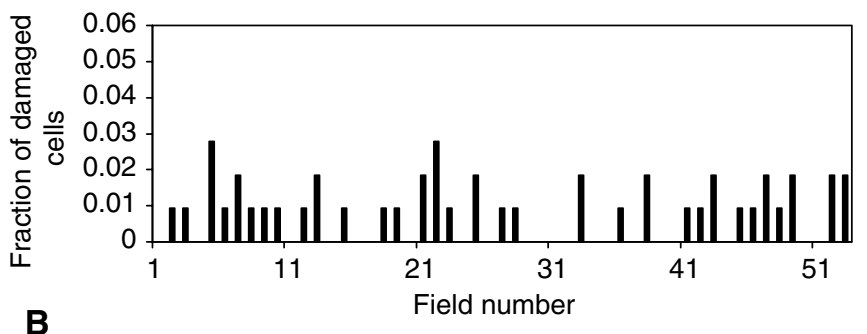

B

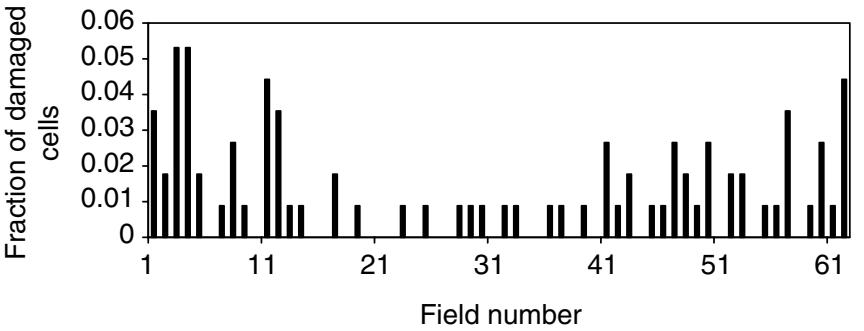

Figure 5 (A) Spatial distribution of the damaged cells in control porcine ureter explant outgrowth is shown. (B) Spatial distribution of the damaged cells after microbeam irradiation of 10 individual cells, each with $10^{3} \mathrm{He}^{2+}$ particles selected at the periphery of the porcine ureter explant outgrowth. Fraction of damaged per field of view, across the explant in $0.1 \mathrm{~mm}$ steps is plotted.

cells irradiated at the actively proliferating edge of a porcine explant outgrowth produce up to 600-4000 additionally micronucleated and apoptotic cells 3 days after irradiation (Table 2).

The spatial distribution of damaged cells within the explants was assessed on selected porcine and human samples. Fractions of damaged cells were calculated per field of view, scanning a straight line across an explant. It was demonstrated that background damaged cells are distributed uniformly throughout the explant outgrowth (Figure 5A). Microbeam irradiation of 10 cells on an actively proliferating edge resulted in additional damaged cells that were concentrated mainly at the periphery of the explant outgrowth (Figure 5B). Spatial distribution of cellular damage after irradiation of 10 cells at the centre of an urothelial explant outgrowth was similar to the background cell damage distribution in the control sample.

There was considerable interindividual variations of bystander response in human and porcine samples (Figure 6). Generally, the human samples demonstrated a higher value of bystander response in comparison with porcine samples (statistically significant for $P<0.05)$. However, control mean values for human

Table 2 Results of experiments of irradiation with $10{ }^{3} \mathrm{He}^{2+}$ particles of 10 individual cell nuclei each distributed on the periphery of a 7-day-old porcine ureter explant outgrowth

\begin{tabular}{|c|c|c|c|c|c|c|c|}
\hline \multirow[b]{2}{*}{ Sample } & \multicolumn{3}{|c|}{ Control } & \multicolumn{3}{|c|}{ Irradiated } & \multirow[b]{2}{*}{$\begin{array}{c}\text { Mean calculated } \\
\text { number of the } \\
\text { additionally } \\
\text { damaged cells }^{\mathbf{a}}\end{array}$} \\
\hline & $\begin{array}{l}\text { Mean number of } \\
\text { damaged cells }\end{array}$ & $\begin{array}{c}\text { Mean calculated } \\
\text { number of cells } \\
\text { within explant } \\
\text { outgrowth }\left(m_{c}\right)\end{array}$ & $\begin{array}{c}\text { Mean fraction of } \\
\text { damaged cells } \pm \text { s.d. } \\
\left(f_{c}\right)\end{array}$ & $\begin{array}{l}\text { Mean number of } \\
\text { damaged cells }\end{array}$ & $\begin{array}{l}\text { Mean calculated } \\
\text { number of cells } \\
\text { within explant } \\
\text { outgrowth }\left(m_{l}\right)\end{array}$ & $\begin{array}{c}\text { Mean fraction of } \\
\text { damaged cells } \pm \text { s.d } \\
\left(f_{\mathrm{I}}\right)\end{array}$ & \\
\hline । & 2663 & $6.2 \times 10^{5}$ & $0.0043 \pm 0.0013$ & 4215 & $5.9 \times 10^{5}$ & $0.0071 \pm 0.001$ & 1698 \\
\hline 2 & 2093 & $4.5 \times 10^{5}$ & $0.0046^{b}$ & 2617 & $4.3 \times 10^{5}$ & $0.0061 \pm 0.0012$ & 663 \\
\hline 3 & 2039 & $8.5 \times 10^{5}$ & $0.0024 \pm 0.0008$ & 4874 & $8.0 \times 10^{5}$ & $0.0061 \pm 0.0011$ & 3050 \\
\hline 4 & 918 & $6.6 \times 10^{5}$ & $0.0014 \pm 0.0011$ & 3568 & $6.6 \times 10^{5}$ & $0.0054 \pm 0.0009$ & 2633 \\
\hline 5 & 1257 & $7.9 \times 10^{5}$ & $0.0016 \pm 0.0009$ & 5236 & $7.9 \times 10^{5}$ & $0.0066 \pm 0.0014$ & 3948 \\
\hline
\end{tabular}

a Mean number of additionally damaged cells is equal to $\left(f_{1}-f_{C}\right) \times\left(m_{C}+m_{1}\right) / 2$.

bingle explant. 


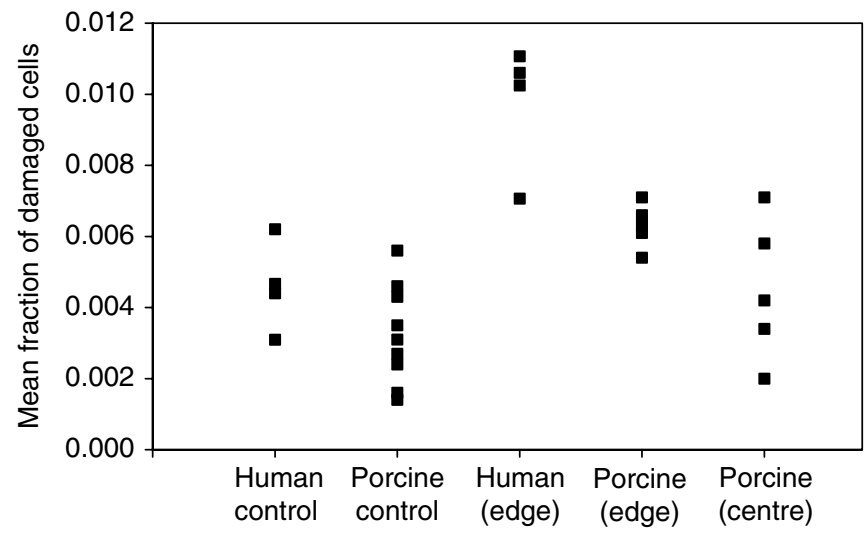

Figure 6 Interindividual variations of the bystander response in human and porcine samples. All squares represent the means of the total cellular damage fractions for every individual sample. Human and porcine controls are compared with human or porcine samples irradiated at the periphery (edge) and porcine samples irradiated at the centre.

samples are not statistically different from the porcine ones $(P<0.05)$. Porcine samples irradiated at the centre demonstrated considerably higher variation in response than those irradiated at the periphery.

\section{DISCUSSION}

Most of the studies on radiation-induced bystander effects have been performed with in vitro cell culture models (Iyer and Lehnert, 2000a). The aim of this approach was to test the role of bystander response in an in vivo-like multicellular system using a microbeam technique for targeting individual cells. An urothelium explant outgrowth system was developed to study bystander effects in a model where dividing and differentiated cells were present. The ureter provides a useful model system for tissue studies. The epithelial layer is highly organised with clear functional delineation between stem, dividing and functionally differentiated cells (Southgate et al, 1995). In the explant model used here, we can reconstruct, in two dimensions, the organisational structure present in three dimensions in the original tissue. The growing explant has an outer region of dividing cells with terminal differentiation occurring toward the centre.

In this model, we have demonstrated evidence for a radiationinduced bystander effect, in both primary human (Figure 3 and Table 1) and porcine (Figure 4A and Table 2) urothelial outgrowth explant systems. The bystander response was found in the explant outgrowth after irradiation of 10 cells, each with 10 individual ${ }^{3} \mathrm{He}^{2+}$ ions, located on the periphery, where actively proliferating cells are found. In terms of absolute numbers, an additional $700-$ 5700 cells could be affected by targeting of only 10 cells, suggesting a cascade mechanism for damage induction. Overall, the bystander effect we report here is small, when taken as a fraction of the total cells within the explant outgrowth, accounting for a two-fold increase in the background frequency of damage. In general, a higher level of bystander response was observed in the human relative to the porcine samples, although there were no significant differences in the morphology and growth characteristics between the two species.

The bystander effect in an in vivo-like urothelial explant system appears to be more substantial than in a purely in vitro primary fibroblast system after targeted low-dose microbeam irradiation as we reported recently (Prise et al, 1998; Belyakov et al, 2001). Those studies were performed with cells at low densities where cell-to-cell contact was minimal and therefore a media-related factor was involved. However, other studies in confluent monolayers of fibroblasts showed that GJIC also played a role in propagation of the bystander effect (Azzam et al, 1998, 2001). Urothelium has highly developed connexin-mediated intercellular communication (Grossman et al, 1994; Lyng et al, 1996) and this could explain the more pronounced bystander effect observed in the urothelial outgrowth in comparison with fibroblast cultures.

The results of our microbeam experiments with irradiation of the explant outgrowth strongly suggest that the proliferative or differentiation state is important for manifestation of the bystander effect. Other evidence towards this conclusion is that micronucleated and apoptotic cells were distributed nonrandomly across the entire area of the explant outgrowth after irradiation of the explant periphery. Damaged cells appeared towards the edges of the outgrowth (Figure 5B). Control samples (Figure 5A) demonstrated a more uniform distribution of the background micronucleated and apoptotic cells, and irradiation of cells at the centre of the explant does not change the spatial distribution in comparison with the control.

Some studies have also suggested that radiation-induced bystander effects may be related to radiation-induced genomic instability (Lorimore et al, 1998; Watson et al, 2000). One potential conclusion from the ureter studies reported here is that the micronucleated and apoptotic cells observed in the explant outgrowth are simply due to the induction of genomic instability in targeted stem or dividing cells. A dose of 10 helium ions to a urothelial cell within the explant outgrowth is equivalent to $\sim 1 \mathrm{~Gy}$ with possibly a $>50 \%$ probability of killing the targeted cell. If out of 10 cells irradiated, five cells survived and exhibited instability in the surviving progeny leading to chromosomal damage, these cells would have to divide through $\sim 8-10$ generations to produce the observed numbers of damaged cells, assuming a high probability of a micronucleated or apoptotic cells being produced. Also, under these conditions it would have been predicted that the micronucleated and apoptotic cells would be located physically close to the originally targeted cell. The typical doubling time of the explants used here is around 2-3 days, and only around $10 \%$ of the explant is dividing (from BUdR labelling). Given this and the fact that no evidence of clustering of micronucleated and apoptotic cells is observed, it is unlikely that the majority of the effect we have observed is due solely to induction of genomic instability.

There are interindividual variations in the measured bystander response (Figure 6), which might be explained by different genetic and physiological backgrounds of the sample donors although we do not have specific information on markers, which may be relevant within the limited number of samples presented here. This raises an important question of individual susceptibility to bystander responses. It has been demonstrated that gap-junction-mediated communication in human bladder explant outgrowth depends on a smoking status of the tissue donors (Lyng et al, 1996). Also, other studies have reported a relationship between the level of bystander signal produced and gender and malignancy status (Mothersill et al, 2001). Further studies in defined populations using the model described here would clearly be useful to clarify the variations in response we have observed.

Our findings contribute to continuing debate regarding the relevance of in vitro cells culture systems to the multicellular tissue system. The role of intercellular communication (including bystander effects) under in vivo conditions might be highly individual and tissue specific. In vitro cell systems are unlikely to exactly mimic the in vivo system response in terms of carcinogenesis. To date, the only other data, where cells within multicellular systems have been targeted with radiation demonstrating bystander responses, have utilised models containing one cell type (Bishayee et al, 1999, 2000). Overall, understanding the role of bystander responses may be important, not just for determining the role of cell-cell communication in radiation responses, but may offer novel approaches to improving therapeutic strategies involving targeted radiotherapy regimens. 
For example, switching on damage-inducing bystander responses in tumour cells may improve the efficacy of targeted radiation approaches or combined gene therapy. Alternatively, it may be possible to protect normal tissues from responding by switching off bystander interactions.

In summary, we have demonstrated evidence of a radiationinduced bystander effect within human and porcine urothelium explant outgrowths where dividing and differentiated cells were present. The bystander response was observed when the actively proliferating region within an explant outgrowth was targeted and the distribution of additional micronucleated and apoptotic cells was nonuniform. This evidence strongly suggests that the expression of bystander damage and proliferation/differentiation state of the cells involved is linked. Further studies will test the underlying mechanisms that lead to signal transduction under these conditions.

\section{ACKNOWLEDGEMENTS}

This work was funded by the Dublin Institute of Technology, Gray Cancer Institute, European Community and Cancer Research UK. We are grateful to Dr Mohi Rezvani and Neil Hubbard (Churchill Hospital, University of Oxford) for provision of porcine ureter samples. We are also grateful to Stuart Gilchrist, Bob Sunderland for their assistance with microbeam operation and Professor Boris Vojnovic, and Dr Simon Ameer-Beg for help with computerassisted image analysis.

\section{REFERENCES}

Abend M, Kehe K, Riedel M, Van Beuningen D (2000) Correlation of micronucleus and apoptosis assays with reproductive cell death can be improved by considering other modes of death. Int J Radiat Biol 76: $249-259$

Abend M, Rhein A, Gilbertz KP, Blakely WF, Van Beuningen D (1995) Correlation of micronucleus and apoptosis assays with reproductive cell death. Int J Radiat Biol 67: 315-326

Azzam EI, de Toledo SM, Gooding T, Little JB (1998) Intercellular communication is involved in the bystander regulation of gene expression in human cells exposed to very low fluences of alpha particles. Radiat Res 150: 497-504

Azzam EI, de Toledo SM, Little JB (2001) Direct evidence for the participation of gap junction-mediated intercellular communication in the transmission of damage signals from alpha-particle irradiated to nonirradiated cells. Proc Natl Acad Sci USA 98: 473-478.

Azzam EI, de Toledo SM, Waker AJ, Little JB (2000) High and low fluences of alpha-particles induce a G1 checkpoint in human diploid fibroblasts. Cancer Res 60: 2623-2631

Belyakov OV, Malcolmson AM, Folkard M, Prise KM, Michael BD (2001) Direct evidence for a bystander effect of ionizing radiation in primary human fibroblasts. Br J Cancer 84: 674-679

Belyakov OV, Prise KM, Trott KR, Michael BD (1999) Delayed lethality, apoptosis and micronucleus formation in human fibroblasts irradiated with X-rays or alpha-particles. Int J Radiat Biol 75: 985-993.

Bishayee A, Rao DV, Bouchet LG, Bolch WE, Howell RW (2000) Protection by DMSO against cell death caused by intracellularly localized iodine125, iodine-131 and polonium-210. Radiat Res 153: 416-427

Bishayee A, Rao DV, Howell RW (1999) Evidence for pronounced bystander effects caused by nonuniform distributions of radioactivity using a novel three-dimensional tissue culture model. Radiat Res 152: 88-97

Cummins RJ, Mothersill C, Seymour CB, Johns H, Joiner MC (1999) The effect of microcolony size, at time of irradiation, on colony forming ability. Int J Radiat Biol 75: 225-232

Folkard M, Vojnovic B, Hollis KJ, Bowey AG, Watts SJ, Schettino G, Prise KM, Michael BD (1997a) A charged particle microbeam: II. A singleparticle micro-collimation and detection system. Int J Radiat Biol 72: 387-395

Folkard M, Vojnovic B, Prise KM, Bowey AG, Locke RJ, Schettino G, Michael BD (1997b) A charged-particle microbeam: I. Development of an experimental system for targeting cells individually with counted particles. Int J Radiat Biol 72: 375-385

Fujiyama C, Masaki Z, Sugihara H (1995) Reconstruction of the urinary bladder mucosa in three-dimensional collagen gel culture: fibroblast extracellular matrix interactions on the differentiation of transitional epithelial cells. J Urol 153: 2060-2067

Grossman HB, Liebert M, Lee IW, Lee SW (1994) Decreased connexin expression and intercellular communication in human bladder cancer cells. Cancer Res 54: $3062-3065$

Hickman A, Jaramillo R, Lechner J, Johnson N (1994) Alpha-particleinduced p53 protein expression in a rat lung epithelial cell strain. Cancer Res 54: $5797-5800$

Hutton KA, Trejdosiewicz LK, Thomas DF, Southgate J (1993) Urothelial tissue culture for bladder reconstruction: an experimental study. J Urol 150: $721-725$
Iyer R, Lehnert BE (2000a) Effects of ionizing radiation in targeted and nontargeted cells. Arch Biochem Biophys 376: 14-25

Iyer R, Lehnert BE (2000b) Factors underlying the cell growth-related bystander responses to alpha particles. Cancer Res 60: 1290-1298

Jen Y, West C, Hendry J (1991) The lower radiosensitivity of mouse kidney cells irradiated in vivo than in vitro: a cell contact effect phenomenon. Int J Radiat Oncol Biol Phys 20: 1243-1248

Kerr JF, Wyllie AH, Currie AR (1972) Apoptosis: a basic biological phenomenon with wide-ranging implications in tissue kinetics. $\mathrm{Br} J$ Cancer 26: 239-257

Lehnert BE, Goodwin EH (1997) Extracellular factor(s) following exposure to alpha particles can cause sister chromatid exchanges in normal human cells. Cancer Res 57: $2164-2171$

Little JB (2000) Radiation carcinogenesis. Carcinogenesis 21: 397-404

Little JB, Nagasawa H, Pfenning T, Vetrovs H (1997) Radiation-induced genomic instability: delayed mutagenic and cytogenetic effects of $\mathrm{X}$ rays and alpha particles. Radiat Res 148: 299-307

Lorimore SA, Kadhim MA, Pocock DA, Papworth D, Stevens DL, Goodhead DT, Wright EG (1998) Chromosomal instability in the descendants of unirradiated surviving cells after alpha-particle irradiation. Proc Natl Acad Sci USA 95: 5730-5733

Lyng FM, de Feijter-Rupp HL, Hayashi T, O’Malley K, Murphy DM, Cottell DC, Trosko JE, Seymour CB, Mothersill C (1996) Effect of a tobaccorelated nitrosamine on intercellular communication in human urothelial cells: a possible factor in smoking-related bladder carcinogenesis. Oncol Res 8: $371-378$

Mothersill C (1998) Development of primary tissue culture techniques for use in radiobiology. Radiat Res 150: $\mathrm{S} 121-\mathrm{S} 125$

Mothersill C, Kadhim MA, O’Reilly S, Papworth D, Marsden SJ, Seymour CB, Wright EG (2000) Dose - and time-response relationships for lethal mutations and chromosomal instability induced by ionizing radiation in an immortalized human keratinocyte cell line. Int J Radiat Biol 76: $799-806$

Mothersill C, Rea D, Wright EG, Lorimore SA, Murphy D, Seymour CB, O'Malley K (2001) Individual variation in the production of a 'bystander signal' following irradiation of primary cultures of normal human urothelium. Carcinogenesis 22: 1465-1471

Mothersill C, Seymour C (1997) Medium from irradiated human epithelial cells but not human fibroblasts reduces the clonogenic survival of unirradiated cells. Int J Radiat Biol 71: 421-427

Nagasawa H, Little JB (1992) Induction of sister chromatid exchanges by extremely low doses of alpha-particles. Cancer Res 52: 6394-6396

Narayanan PK, Goodwin EH, Lehnert BE (1997) Alpha particles initiate biological production of superoxide anions and hydrogen peroxide in human cells. Cancer Res 57: 3963-3971

Petzoldt JL, Leigh IM, Duffy PG, Masters JR (1994) Culture and characterisation of human urothelium in vivo and in vitro. Urol Res 22: $67-74$

Prise KM, Belyakov OV, Folkard M, Michael BD (1998) Studies of bystander effects in human fibroblasts using a charged particle microbeam. Int $J$ Radiat Biol 74: $793-798$

Reznikoff CA, Johnson MD, Norback DH, Bryan GT (1983) Growth and characterization of normal human urothelium in vitro. In Vitro 19: $326-343$ 
Sigg M, Crompton NE, Burkart W (1997) Enhanced neoplastic transformation in an inhomogeneous radiation field: an effect of the presence of heavily damaged cells. Radiat Res 148: $543-547$

Southgate J, Kennedy W, Hutton KA, Trejdosiewicz LK (1995) Expression and in vitro regulation of integrins by normal human urothelial cells. Cell Adhes Commun 3: 231-242

Vojnovic B (1996) Advanced Technology Development. In Gray Laboratory Research Report 1995 pp 31 -36. Northwood: Gray Laboratory

Ward J (1999) New paradigms for low-dose radiation response. In Proceedings of the American Statistical Association Conference on Radiation and Health, San Diego, California, USA, June 14-17, 1998. Radiat Res 151: $92-117$
Watson GE, Lorimore SA, Macdonald DA, Wright EG (2000) Chromosomal instability in unirradiated cells induced in vivo by a bystander effect of ionizing radiation. Cancer Res 60: $5608-5611$

Workman P, Twentyman P, Balkwill F, Balmain A, Chaplin D, Double J, Embleton J, Newell D, Raymond R, Stables J, Stephens T, Wallace J (1998) United Kingdom Coordinating Committee on Cancer Research (UKCCCR) Guidelines for the Welfare of Animals in Experimental Neoplasia (2nd edn). Br J Cancer 77: 1-10

Zhou H, Randers-Pehrson G, Waldren CA, Vannais D, Hall EJ, Hei TK (2000) Induction of a bystander mutagenic effect of alpha particles in mammalian cells. Proc Natl Acad Sci USA 97: 2099-2104 